\title{
DIETARY PROBIOTIC Lactobacillus plantarum L-211 FOR FARM ANIMALS. I. THE ADDITIVE FOR BROILER CHICKS (Gallus gallus L.)
}

\section{V.I. FISININ1, E.N. ANDRIANOVA', I.I. CHEBOTAREV ${ }^{2}$, G.Yu. LAPTEV 3 , I.N. NIKONOV 3 , L.A. IL'INA ${ }^{3}$, A.V. SAVINOV ${ }^{2}$, N.G. MASHENTSEVA, D.L. KLABUKOVA ${ }^{4}$, E.A. YILDIRIM ${ }^{3}$, N.I. NOVIKOVA ${ }^{3}$}

\author{
1Federal Scientific Center All-Russian Research and Technological Poultry Institute RAS, Federal Agency of Sci- \\ entific Organizations, 10, ul. Ptitsegradskaya, Sergiev Posad, Moscow Province, 141311 Russia, e-mail eandria- \\ nova.andrianova@yandex.ru, olga@vnitip.ru; \\ ${ }^{2} J S C$ «Bioreactor», 18, ul. Komarova, Shchelkovo, Moscow Province, 114142 Russia; \\ 3JSC «Biotrof», Kolpino, St. Petersburg, 192288 Russia, e-mail nikonov@biotrof.ru (corresponding author); \\ ${ }^{4}$ Moscow State University of Food Production, 11, Volokolamskoe sh., Moscow, 125080 Russia \\ ORCID: Fisinin V.I. orcid.org/0000-0003-0081-6336 \\ The authors declare no conflict of interests \\ Acknowledgements: \\ Supported financially under the subsidy agreement with Ministry of Education and Science of the Russian Federa- \\ tion № 14.579.21.0021 dated 05.06.2014 \\ Received October 3, 2016
}

\section{Abstract}

Lysine is an essential limiting amino acid in chick feeding. Its deficiency in feeds, especially of wheat-barley or corn-sunflower type, can reach 15-20\%. Dietary synthetic amino acids may negatively influence productivity due to imbalances caused by rapid amino acids entry into blood. This study continues a series of our experiments aimed at determining the efficiency of dietary synthetic lysine replacement by the microorganisms that synthesize L-lysine. Previous studies have shown a high positive effect of lysine producing Escherichia coli (Prolizer-BioR probiotic; JSC «Bioreactor», Moscow), however, seeking for similar producers among non-pathogenic microorganisms remains important. In this paper we present the findings in the support of Lactobacillus plantarum L211 probiotic (JSC «Bioreactor», Moscow) ability to optimize the gut microflora in view to increase the productive performance in poultry. Using the T-RFLP (terminal restriction fragment length polymorphism), we compared the cecal bacterial community in four groups of Cobb 500 broiler chickens at 35 days of age. The diet in group 1 (control) was a balanced combined feed. The broilers of groups 2, 3 and 4 were fed with dietary domestic probiotics containing lysine-producing Lactobacillus plantarum L-211, L. plantarum which does not produce lysine, or Bacillus subtilis (a daily rate of $1 \mathrm{ml}$ for lactobacilli and $2 \mathrm{ml}$ for bacilli). The concertation of all live bacteria was 100 million CFU/ml. Lysine producing $L$. plantarum L-211 increased the level of lactobacilli by 3.88 times $(\mathrm{P}<0.005)$, of cellulolytic and amylolytic Clostridia by 1.13 times, and of acid utilizing Negativicutes by 1.36 times $(\mathrm{P}<0.05)$, whereas, on the contrary, reduced the portion of pathogenic peptococci by 1.35 times $(\mathrm{P}<0.05)$, staphylococci by 1.46 times and enterobacteria by 2.33 times $(\mathrm{P}<0.005)$. However, L. plantarum L211, unlike L. plantarum or B. subtilis, did not affect the Fusobacteria or Enterobacteriaceae counts. Also, L. plantarum L-211 was not effective against pasteurella and actinomycetes which, on the contrary, increased in number 1.33 - and 2.75 -fold $(\mathrm{P}<0.005)$ as compared to the control. The lysineproducing probiotic strain resulted in the highest average live weight in broilers at day 35 and the highest average daily weigh gain $(5.01 \%$ and $5.14 \%$, respectively). L. plantarum L-211 also led to the lowest availability of lysine in the diet.

Keywords: lysine, gut microflora, broilers, bacterial community, T-RFLP, probiotics, Lactobacillus plantarum, productivity, broiler chicken survival rates, feed conversion ratio

Ensuring high productivity in commercial poultry farming necessitates feeds which are balanced in all nutrients. Lysine, the essential limiting amino acid, is of particular importance. In vegetable feeds, its content is low and often not enough for animal and poultry diets, especially those with predominating cereals, sunflower meal and a small fraction (1-2\%) of ingredients of animal origin. In rations of wheat-barley and corn-sunflower type, the deficit of lysine can reach $15-20 \%$. Therefore, dietary synthetic lysine [1-3] is widely used for 
balancing.

It is known that the introduction of synthetic amino acids in the diet must be limited because of their rapid absorption into the blood, as compared to amino acids of plant and animal origin metabolized in digestion, which leads to an imbalance of amino acids in the body and negatively affects productivity. Synthetic lysine monochlorohydrate leads to an excess of chlorine in combined feed and, as a consequence, to its imbalance, which also negatively affects productivity [4].

At present, feed additives based on bacteria that produce amino acids and other essential substances are used worldwide in poultry farming [5-7]. When studying the effect of the domestic bacterial preparation Prolisar-BioR, the efficiency of replacing synthetic lysine with its producer, thr strain Escherichia coli [8-10] was found. However, E. coli belongs to conditionally pathogenic microflora of the gastrointestinal tract and is a causative agent of colibacillosis in chickens when immunity is weakened [11-13]. Despite the fact that in our studies of lysine-producing non-pathogenic $E$. coli strain there were no cases of colibacillosis [14], searching for lysine producers of non-pathogenic microflora, e.g. lactobacilli, remains relevant.

The strain Lactobacillus plantarum L-211 was identified by analysis of 16S rRNA gene with a homology of $99 \%$. Phenotypically, strain L. plantarum L-211 is a small non spore-forming mesophilic facultative anaerobic grampositive rod-like bacterium. According to biochemical signs, the microorganism is unable to metabolize glucose to $\mathrm{CO}_{2}$ and to produce hydrogen sulphide and indole, is catalase negative, gelatin thinning, possessing nitrate reductase activity, reducing litmus milk, hydrolyzing L-arginine and fermenting most carbohydrates. Technologically, L. plantarum L-211 is characterized by acid formation of $80^{\circ} \mathrm{T}$ in 24 hours, the limit of acid formation is $140{ }^{\circ} \mathrm{T}$ (7 days). The microorganism does not decarboxylate amino acids, therefore, the biogenic amines, histamine, tyramine, putrescine, cadaverine, are not forming. In mineral media, L. plantarum L-211 is capable of producing $148.4 \pm 4.45 \mathrm{mg} / \mathrm{l}$ lysine [14].

In this paper, we have shown for the first time the possibility to optimize the microflora of the gastrointestinal tract of the birds and their providing with amino acids, including lysine, using a $L$. plantarum L-211 based biological.

Our objective was to study the influence of the lysine producer L. plantarum L-211 on intestine bacterial community and productivity in broiler chickens.

Technique. Cobb 500 broilers (Gallus gallus L.) were divided into four groups, 35 heads each, and examined during day 1 to day 35 period of life in the vivarium FGUP Zagorskoye EPH VNITIP (Moscow Province). Chicks of the group I (control) were fed with combined feed balanced for all nutrients (basic diet, BD) as per the norms [1]. The bird in group II received the BD supplemented with a $L$. plantarum L-211 probiotic at a daily rate of $1 \mathrm{ml}$ per head (OOO Bioreactor, Moscow), in group III the BD was supplemented with a developed domestic preparation based on $L$. plantarum at a daily rate of $1 \mathrm{ml}$ per head dosage, in group IV a domestic probiotic additive based on Bacillus subtilis was used at a daily rate of $2 \mathrm{ml}$ per head. In the preparations, the counts of living microorganisms were 100 million $\mathrm{CFU} / \mathrm{ml}$. The chickens were kept in AviMax cage batteries (Big Dutchman International GmbH, Germany) according to the technological parameters of VNITIP without separation by sex.

During the experiment, the main zootechnical indicators were recorded, i.e. live weight at 7-, 14-, 21-, 28-day-old age and by the end of experiment in individual weighing, survivability, daily weight gain, feed consumption and feed costs per $1 \mathrm{~kg}$ of live weight gain. In the physiological balance experiment on 35day-old broilers, the digestibility of proteins, fat, the use of nitrogen, calcium, 
phosphorus, the availability of methionine and lysine were determined [15, 16].

For molecular genetic studies, the cecum contents were collected at slaughtering on day 35 with strict sterility according to the requirements [16]. The composition of cecum bacterial community was examined by T-RFLP (terminal restriction fragment length polymorphism) method [17, 18]. Total DNA for T-RFLP analysis was isolated using the Genomic DNA Purification Kit (Fermentas, Inc., Lithuania) according to the manufacturer's protocol. PCR was performed on a Verity DNA amplifier (Life Technologies, Inc., USA) with eubacterial primers 63F (CAGGCCTAACACATGCAAGTC) labeled at the 5'end (WellFed D4 fluorophore, Beckman Coulter, Inc., USA) and 1492R (TACGGHTACCTTGTTACGACTT). Labeled amplicons of 16S rRNA gene DNA was purified by a standard procedure [18]. The resulting amplicons (30-50 ng) were restricted with HaeIII, HhaI and MspI endonucleases as per the manufacturer's recommendations (Fermentas, Inc., Lithuania). The restricts were examined using genetic analysis system CEQ $^{\mathrm{TM}} 8000$ (Beckman Coulter Inc., USA) according by the manufacturer's protocol. For phylogenetic affiliation, Fragment Sorter program (http://www.oardc.ohiostate.edu/trflpfragsort/index.php) was used.

For statistical processing, the variance analysis was performed in $\mathrm{Mi}$ crosoft Excel 2010. Mean $(X)$ and mean errors $(x)$ were calculated. Differences with the control were considered significant at $\mathrm{P}<0.05 ; \mathrm{P}<0.01$ and $\mathrm{P}<0.005$.

Results. Chicks were fed manually with dry feeds in full according to the norms of VNITIP for the cross (Table 1).

1. Composition of experimental combined feeds (base ration) for growing Cobb $\mathbf{5 0 0}$ broilers

\begin{tabular}{|c|c|c|}
\hline Ingredient, \% & Days 1-21 & Days 22-35 \\
\hline Wheat & 42.57 & 55.20 \\
\hline Corn & 10.00 & 0 \\
\hline Sunflower fodder cake (protein content $34 \%$ ) & 9.86 & 7.18 \\
\hline Soybean oil & 2.65 & 5.00 \\
\hline Choline chloride & 0.07 & 0.07 \\
\hline Soy fatty fodder (protein content $34 \%$ ) & 25.00 & 23.94 \\
\hline Fish meal fodder (protein content $65 \%$ ) & 7.00 & 6.00 \\
\hline Methionine fodder (not less than 99\%) & 0.27 & 0.23 \\
\hline Lysine fodder (not less than $78 \%$ ) & 0.41 & 0.27 \\
\hline Monocalcium phosphate & 0.47 & 0.59 \\
\hline Lime & 1.36 & 1.13 \\
\hline $\mathrm{NaCl}$ & 0.24 & 0.29 \\
\hline Premix (VNITIP, Russia) & 0.10 & 0.10 \\
\hline \multicolumn{3}{|l|}{ Total per $100 \mathrm{~g}$ combined feed, $\%$ : } \\
\hline dry matter & 86.45 & 84.30 \\
\hline metabolic energy, kcal & 310 & 320 \\
\hline crude protein & 22.50 & 21.00 \\
\hline lipids & 9.82 & 11.46 \\
\hline linoleic acid & 4.68 & 5.52 \\
\hline crude cellulose & 5.05 & 4.63 \\
\hline lysin & 1.45 & 1.25 \\
\hline methionine & 0.66 & 0.58 \\
\hline methionine + cystine & 0.99 & 0.89 \\
\hline threonine & 0.80 & 0.74 \\
\hline tryptophan & 0.26 & 0.25 \\
\hline $\mathrm{Ca}$ & 1.00 & 0.89 \\
\hline $\mathrm{P}$ & 0.68 & 0.67 \\
\hline$P$ digestible & 0.39 & 0.39 \\
\hline $\mathrm{Na}$ & 0.20 & 0.20 \\
\hline $\mathrm{K}$ & 0.72 & 0.69 \\
\hline $\mathrm{Cl}$ & 0.34 & 0.33 \\
\hline choline & 0.05 & 0.05 \\
\hline
\end{tabular}

T-RFLP analysis showed (Table 2) that the microorganisms of five phyla, i.e. Firmicutes, Bacteroidetes, Actinobacteria, Proteobacteria and Fusobacteria, were identified in all groups, which was in line with our previous findings on cecum microbiome [19-21]. The representatives of phylum Firmicutes predomi- 
nated, mainly cellulolytic and amylolytic bacteria of class Clostridia (families Ruminococcaceae, Eubacteriaceae, Lachnospiraceae, Clostridiaceae, etc.), acid utilizing bacteria of order Negativicutes, and families Bacillaceae and Lactobacillaceae. Bacteria of other phyla were less abundant.

Among conditionally pathogenic and pathogenic microorganisms, we found families Campylobacteriaceae, Enterobacteriaceae, Pasterellaceae, Actinobacteriaceae, phylum Fusobacteria, and the genera Peptococcus and Staphylococcus.

2. The bacterial taxa $(\%)$ in cecum of 35 day old Cobb 500 broilers fed with domestic dietary probiotics $(X \pm x$, vivarium FGUP Zagorskoye EPH VNITIP, Moscow Province)

\begin{tabular}{|c|c|c|c|c|}
\hline Taxon & $\begin{array}{l}\text { Group I (con- } \\
\text { trol, } n=3 \text { ) }\end{array}$ & $\begin{array}{l}\text { Group II } \\
(n=3)\end{array}$ & $\begin{array}{l}\text { Group III } \\
(n=3)\end{array}$ & $\begin{array}{l}\text { Group IV } \\
(n=3)\end{array}$ \\
\hline Phylum Bacteroidetes & $2.04 \pm 0.10$ & $3.01 \pm 0.12^{* *}$ & $2.76 \pm 0.14^{*}$ & $2.65 \pm 0.10^{*}$ \\
\hline Phylum Firmicutes & $53.71 \pm 2.43$ & $60.17 \pm 2.84$ & $43.28 \pm 2.11 *$ & $63.80 \pm 3.01$ \\
\hline class Clostridia & $31.14 \pm 1.15$ & $35.08 \pm 1.26$ & $21.74 \pm 1.01 * *$ & $40.14 \pm 1.98^{*}$ \\
\hline genus Peptococcus & $2.36 \pm 0.14$ & $1.75 \pm 0.05^{*}$ & $1.27 \pm 0.07 * *$ & $1.94 \pm 0.08$ \\
\hline genus Lactobacillus & $1.72 \pm 0.08$ & $6.63 \pm 0.31 * * *$ & $11.00 \pm 0.49 * * *$ & $10.60 \pm 0.60 * * *$ \\
\hline genus Bacillus & $10.60 \pm 0.43$ & $6.45 \pm 0.23^{* *}$ & $4.40 \pm 0.21 * * *$ & $3.34 \pm 0.14 * * *$ \\
\hline genus Staphylococcus & $0.67 \pm 0.23$ & $0.46 \pm 0.21$ & $0.38 \pm 0.14$ & $0.26 \pm 0.11$ \\
\hline order Negativicutes & $7.22 \pm 0.29$ & $9.80 \pm 0.42^{*}$ & $4.49 \pm 0.19 * *$ & $7.52 \pm 0.39$ \\
\hline Phylum Actinobacteria & $2.82 \pm 0.13$ & $7.76 \pm 0.30 * * *$ & $2.43 \pm 0.12$ & $6.11 \pm 0.30^{* * *}$ \\
\hline семейство Bifidobacteriaceae & $0.12 \pm 0.01$ & Brd & $0.07 \pm 0.01^{*}$ & $0.04 \pm 0.01^{* *}$ \\
\hline Phylum Proteobacteria & $29.29 \pm 1.14$ & $13.40 \pm 0.59^{* *}$ & $25.47 \pm 1.02$ & $15.06 \pm 0.62^{* * *}$ \\
\hline family Enterobacteriaceae & $14.10 \pm 0.65$ & $6.04 \pm 0.29 * * *$ & $15.70 \pm 0.78$ & $1.07 \pm 0.04 * * *$ \\
\hline family Campylobacteriaceae & $2.08 \pm 0.09$ & $2.23 \pm 0.06$ & $1.92 \pm 0.08$ & $1.47 \pm 0.06^{* *}$ \\
\hline family Pseudomonadaceae & $9.43 \pm 0.58$ & $1.71 \pm 0.05^{* * *}$ & $5.12 \pm 0.09 * *$ & $8.12 \pm 0.27$ \\
\hline family Pasteurellaceae & $1.32 \pm 0.22$ & $1.76 \pm 0.11$ & $1.46 \pm 0.12$ & $2.46 \pm 0.42$ \\
\hline Phylum Fusobacteria & $2.58 \pm 0.14$ & $2.52 \pm 0.12$ & $1.56 \pm 0.10^{* *}$ & $2.18 \pm 0.17$ \\
\hline Unclassified sequences & $9.56 \pm 0.59$ & $13.05 \pm 0.65$ & $24.50 \pm 1.21^{* * *}$ & $10.20 \pm 0.52$ \\
\hline
\end{tabular}

$\mathrm{N}$ o t e. In the groups II, III and IV, the Lactobacillus plantarum L-211, L. plantarum and Bacillus subtilis probiotics, respectively, were added to the basic (control) diet (for more details, see the Technique section). Brd - below reliable determination by T-RFLP

$*, * *, * * *$ Differences with control are statistically significant at $\mathrm{P}<0.05$, respectively; $\mathrm{P}<0.01$ and $\mathrm{P}<0.005$.

We found that the introduction of live probiotic bacteria into the diet of broilers led to a change in the number of identified taxa in cecum, which had similar tendencies for birds from experimental groups. Thus, in chickens, fed with probiotics, the proportion of genus Lactobacillus bacteria, which, as a rule, exhibits significant antagonistic properties against pathogenic species due to the synthesis of antimicrobial compounds [22, 23], increased 3.88 ( $\mathrm{P}<0.005), 6.40(\mathrm{P}<0.005)$ and 6.12 times $(\mathrm{P}<0.005)$ for groups II, III and IV, respectively, compared to control. The counts of other bacteria with similar activity against pathogens, the bacilli, decreased $1.13(\mathrm{P}<0.01), 1.43(\mathrm{P}<0.005)$ and 1.29 times $(\mathrm{P}<0.005)$, respectively. In addition, in these groups, the bacteria of Bacteroidetes phylum involved in fermentation of carbohydrates due to amylolytic and cellulolytic activity, increased $1.48(\mathrm{P}<0.01), 1.35 \mathrm{P}<0.05)$ and 1.30 times $(\mathrm{P}<0.05)$, respectively, compared to control.

However, the effect of the preparations studied was not the same for bacteria of class Clostridia with amylo- and cellulolytic properties. Additives of the lysine producer L. plantarum L-211 and B. subtilis contributed to a 1.13-fold and 1.29-fold $(\mathrm{P}<0.05)$ increase in the proportion of bacteria from the Clostridia class, respectively, whereas feeding with $L$. plantarum, not producing lysine, on the contrary, reduced this index 1.43 times $(\mathrm{P}<0.01)$ compared to control. The effect of the L. plantarum L-211 preparation against Clostridia members is consistent with the data of foreign authors who showed that the lack of lysine in the diets reduces the number of genus Eubacterium in the cecum [24].

A similar trend was noted for acid utilizing bacteria of the order Negativicutes. Dietary lysine producer contributed their 1.36 -fold increase $(\mathrm{P}<0.05)$, whereas lactobacillus not synthesizing lysine caused a 1.61 -fold decrease $(\mathrm{P}<0.01)$ compared to control. 
It should be noted that the additives contributed to a decrease in the number of pathogens in the cecum. All additives affected the proportion of pathogens causing purulent-necrotic infections. Counts of peptococci decreased $1.35(\mathrm{P}<0.05), 1.86(\mathrm{P}<0.01)$ and 1.22 times, of staphylococci was $1.46,1.76$ and 2.58 times lower in groups II, III and IV, respectively. Additionally, the lysine producer 2.33 times $(\mathrm{P}<0.005)$ reduced the counts of enterobacteria, the causative agent of gastroenteritis. The $B$. subtilis proved its effectiveness against enterobacteria and campylobacteria, the causative agents of gastroenteritis, and fusobacteria, the causative agents of purulent-necrotic infections in animals and birds), resulting in a $13.17(\mathrm{P}<0.005), 1.41(\mathrm{P}<0.01)$ and 1.18 times decrease, respectively. Lactobacilli not synthesizing lysine, were effective against fusobacteria decreasing their counts 1.65 times $(\mathrm{P}<0.01)$.

On the other hand, no effect of probiotics was observed against some pathogens. In groups II and IV there was a tendency to 1.33- and 1.76-fold increase, respectively, for pasteurellas which cause respiratory infections in chicks, and a 2.75-fold $(\mathrm{P}<0.005)$ and 2.16-fold $(\mathrm{P}<0.005)$ increase for undesirable actinomycetes of which some can cause actinomycosis.

Interestingly, in use of probiotics, the counts of Pseudomonadaceae representatives, which belong to transit microorganisms entering the body with food, decreased in cecum $5.51(\mathrm{P}<0.005), 1.84(\mathrm{P}<0.01)$ and 1.16 times, and of unidentified taxa increased 1.25, $2.18(\mathrm{P}<0.005)$ and 1.08 times in groups II, III and IV, respectively.

3. Main zootechnical indices in 35 day old Cobb 500 broilers fed with domestic dietary probiotics $(X \pm x$, vivarium FGUP "Zagorskoye EPH VNITIP", Moscow Province)

\begin{tabular}{|c|c|c|c|c|}
\hline Indices & $\begin{array}{l}\text { Group I } \\
(\text { control, } n=3)\end{array}$ & $\begin{array}{l}\text { Group II } \\
(n=3)\end{array}$ & $\begin{array}{l}\text { Group III } \\
(n=3)\end{array}$ & $\begin{array}{l}\text { Group IV } \\
(n=3)\end{array}$ \\
\hline Stock preservation, $\%$ & 97.1 & 94,3 & 100 & 97,1 \\
\hline \multicolumn{5}{|l|}{ Live bodyweight, g: } \\
\hline on day 1 & $40.0 \pm 1.98$ & $40,0 \pm 2,18$ & $40,00 \pm 2,14$ & $40,00 \pm 1,16$ \\
\hline on day 7 & $120.22 \pm 2.88$ & $112,22 \pm 3,25$ & $117,44 \pm 2,77$ & $114,22 \pm 2,84$ \\
\hline on day 14 & $323.21 \pm 7.90$ & $315,24 \pm 7,54$ & $323,45 \pm 8,39$ & $309,63 \pm 8,50$ \\
\hline on day 21 & $708.42 \pm 13.72$ & $668,42 \pm 14,44$ & $698,16 \pm 14,95$ & $671,58 \pm 14,35$ \\
\hline on day 28 & $1128.0 \pm 36.89$ & $1054,57 \pm 22,2$ & $1110,14 \pm 38,30$ & $1142,57 \pm 26,60$ \\
\hline on day 35 & $1697.65 \pm 39.27$ & $1739,68 \pm 33,17$ & $1691,33 \pm 32,38$ & $1687,20 \pm 39,85$ \\
\hline including males & $1882.50 \pm 38.97$ & $1947,0 \pm 42,84$ & $1900,0 \pm 26,42$ & $1927,501 \pm 37,17$ \\
\hline including females & $1533.34 \pm 32.98$ & $1640,95 \pm 23,06^{*}$ & $1587,0 \pm 22,74$ & $1574,2 \pm 26,86$ \\
\hline mean & $1707.92 \pm 35.16$ & $1793,5 \pm 33,19$ & $1743,5 \pm 25,81$ & $1750,85 \pm 31,45$ \\
\hline Feed conversion rate per broiler, $\mathrm{kg}$ & 2.748 & 2,779 & 2,681 & 2,635 \\
\hline $\begin{array}{l}\text { Food consumption per } \mathrm{kg} \text { of weight } \\
\text { gain, kg }\end{array}$ & 1.657 & 1,635 & 1,624 & 1,599 \\
\hline Average daily weight gain, $\mathrm{g}$ & 49.05 & 51,57 & 50,10 & 50,32 \\
\hline \multicolumn{5}{|c|}{$\begin{array}{l}\text { N o t e. In the groups II, III and IV, probiotic preparations were added to the main (control) diet on the basis of } \\
\text { Lactobacillus plantarum L-211, L. plantarum and Bacillus subtilis, respectively (for more details, see the Technique } \\
\text { section). } \\
\text { * Differences with control are statistically significant at } \mathrm{P}<0.05 \text {. }\end{array}$} \\
\hline
\end{tabular}

The poultry viability (Table 3 ) varied, with a difference of $3.7 \%$, depending on the probiotic used and was greatest in group III, where it was $2.9 \%$ higher than in control and in group IV, and $5.7 \%$ higher than in group II. The dynamics of live weight also differed depending on the group. Up to day 28 the control broilers had the largest live weight, on day 35 those of group II fed with dietary lysine producer L. plantarum L-211 was superior to other to other groups. The average live weight of the chickens of group II was $5.01 \%$ higher compared to control, the males exceeded the control counterparts in live weight by $3.4 \%$, and the females exceeded by $7.0 \%(\mathrm{P}<0.05)$. Feed costs per $1 \mathrm{~kg}$ of live weight gain in group II decreased and was $1.635 \mathrm{~kg}$ vs. $1.657 \mathrm{~kg}$ in the control. Probably, the lower zootechnical indices for live weight in chickens from group II during the first growing period are associated with the use of the dietary 
probiotic when lysine level in the diet was normative, which requires additional studies on its dosage.

It is necessary to note a slight lag in the live weight in group III, receiving L. plantarum, compared to control which was observed during the first period of fattening and was mainly due to the large number of females in the group. In the second period, the average live weight of broilers in group III exceeded the indicator in control by $2.08 \%$ (by 0.93 and $3.50 \%$ for males and females, respectively). At that, the feed costs per $1 \mathrm{~kg}$ of the live weight gain were below the control by $1.99 \%$.

In group IV with dietary $B$. subtilis the growth rate of the chicks on day 28 was higher, they were superior to group I in live weight with the control values exceeded by $1.30 \%$ on day 28 , and by $2.51 \%$ to the end of fattening. Dietary B. subtilis probiotic also allowed to obtain the lowest feed costs per $1 \mathrm{~kg}$ of live weight gain, i.e. $1,599 \mathrm{~kg}$ vs. $1.657 \mathrm{~kg}$ in group I.

The results of physiological (balance) experiment (Table 4) were generally consistent with productivity. Thus, in all experimental groups the digestibility of the dry matter and the nutrients tended to decrease compared to control. We noted a lower digestibility of proteins, dry matter, fat and the use of nitrogen in chicks from groups II-IV, which indicates the need to adjust the way of application and dosage of probiotics (for example, use the intermittent supply with water). Note that not synthesizing lysine strain L. plantarum contributed to an increase in digestibility of cellulose by $0.5 \%$ compared to control.

Higher availability of lysine was noted in chickens from groups III and IV who received bacteria not capable of producing lysine $(93.8 \%$ and $94.4 \%$ vs $92.8 \%$ in control).

4. Use of feed nutrients in 35-day old Cobb 500 broilers fed with dietary probiotics ( $X \pm x$, vivarium FGUP "Zagorskoye EPH VNITIP", Moscow Province)

\begin{tabular}{|c|c|c|c|c|}
\hline Indices & $\begin{array}{l}\text { Group I } \\
\text { (control, } n=3)\end{array}$ & $\begin{array}{l}\text { Group II } \\
(n=3)\end{array}$ & $\begin{array}{l}\text { Group III } \\
(n=3)\end{array}$ & $\begin{array}{l}\text { Group IV } \\
(n=3)\end{array}$ \\
\hline \multicolumn{5}{|l|}{ Digestibility, \%: } \\
\hline proteins & $94.7 \pm 1.12$ & $92.20 \pm 1.32$ & $93.90 \pm 0.98$ & $93.10 \pm 1.19$ \\
\hline dry matter & $73.7 \pm 1.26$ & $67.00 \pm 0.67$ & $71.00 \pm 1.24$ & $69.60 \pm 1.14$ \\
\hline lipids & $83.2 \pm 1.01$ & $80.20 \pm 1.85$ & $81.30 \pm 2.13$ & $80.10 \pm 0.95$ \\
\hline cellulose & $29.5 \pm 1.14$ & $21.00 \pm 0.96$ & $30.00 \pm 1.43$ & $24.40 \pm 1.32$ \\
\hline \multicolumn{5}{|c|}{ Metabolized elements, \%: } \\
\hline nitrogen & $66.7 \pm 1.16$ & $61.30 \pm 2.01$ & $61.70 \pm 1.95$ & $60.00 \pm 1.39$ \\
\hline calcium & $48.0 \pm 2.14$ & $49.30 \pm 1.56$ & $48.60 \pm 1.04$ & $47.70 \pm 1.54$ \\
\hline phosphorus & $44.9 \pm 1.75$ & $47.90 \pm 1.22$ & $44.50 \pm 2.01$ & $42.80 \pm 1.95$ \\
\hline \multicolumn{5}{|l|}{ Availability, \%: } \\
\hline lysine & $92.8 \pm 1.13$ & $90.10 \pm 0.95$ & $93.80 \pm 0.68$ & $94.40 \pm 1.16$ \\
\hline methionine & $84.1 \pm 1.05$ & $80.10 \pm 1.65$ & $77.10 \pm 1.25$ & $78.80 \pm 1.82$ \\
\hline \multicolumn{5}{|c|}{$\begin{array}{l}\mathrm{N} \text { o t e. In the groups II, III and IV, probiotic preparations were added to the main (control) diet on the basis of } \\
\text { Lactobacillus plantarum L-211, L. plantarum and Bacillus subtilis, respectively (for more details, see the Technique } \\
\text { section). }\end{array}$} \\
\hline
\end{tabular}

Thus, the use of dietary L. plantarum L-211 had a pronounced effect on the cecum bacterial community. Unlike the two other bacterial probiotics studied, the L. plantarum L-211 promotes a simultaneous increase in of cellulolytic and amylolytic Clostridia and Negativicutes bacteria. In addition, it has probiotic activity, affecting positively the number of lactobacilli and reducing opportunistic and pathogenic microflora including peptococci, staphylococci, and enterobacteria. It should be noted that dietary L. plantarum L-211 did not reduce the number of fusobacteria which were suppressed by the lactobacilli non synthesizing lysine, and campylobacteria which were suppressed by dietary B. subtilis. Nevertheless, the probiotics were not effective against some pathogens, and, moreover, L. plantarum L-211 resulted in an increase in pasteurellas and actinomycetes compared to control.

So, our studies have confirmed the possibility of using a probiotic strain 
Lactobacillus plantarum L-211 to improve the productivity of broilers. This dietary additive showed the best results for the average live weight on day 35 and the average daily weight gain. In the poultry receiving probiotics that do not have the ability to synthesize lysine, the availability of lysine was higher. The effect of the probiotics studied on cecum composition of pathogenic, opportunistic, transit microorganisms and actinomycetes differes depending on the bacterial preparation and the growing period, which indicates the reserves of increasing effectiveness of probiotic supplements by adjusting the regimens and the doses of their introduction into the diet.

\section{REFEREN C ES}

1. Normy i ratsiony kormleniya sel'skokhozyaistvennykh zhivotnykh. Spravochnoe posobie /Pod redaktsiei A.P. Kalashnikova, V.I. Fisinina, V.V. Shcheglova, N.I. Kleimenova [Norms and rations of feeding of farm animals. Reference Manual. A.P. Kalashnikov, V.I. Fisinin, V.V. Shcheglov, N.I. Kleimenov (eds.)]. Moscow, 2003 (in Russ.).

2. Panda A.K., Rao S.V., Raju M.V., Niranjan M., Reddy M.R. Effect of nutrient density on production performance, egg quality and humoral immune response of brown laying (Dahlem Red) hens in the tropics. Trop. Anim. Health Prod., 2012, 44(2): 293-299 (doi: 10.1007/s11250-011-0017-9).

3. Ospina-Rojas I.C., Murakami A.E., Eyng C., Nunes R.V., Duarte C.R., Vargas M.D. Commercially available amino acid supplementation of low-protein diets for broiler chickens with different ratios of digestible glycine + serine:lysine. Poultry Sci., 2012, 91(12): 3148-3155 (doi: 10.3382/ps.2012-02470).

4. W e c k e C., Li e b e r t F. Improving the reliability of optimal in-feed amino acid ratios based on individual amino acid efficiency data from $\mathrm{n}$ balance studies in growing chicken. Animals (Basel), 2013, 3(3): 558-573 (doi: 10.3390/ani3030558).

5. Alhotan R.A., Pest i G.M. Quantitative estimates of the optimal balance between digestible lysine and the true protein contents of broiler feeds. Brit. Poultry Sci., 2016, 57(4): 538-550 (doi: 10.1080/00071668.2016.1180666).

6. Kabisov R., Tsugki e v B., K ho z i e v A. Ptitsevodstvo, 2010, 5: 40-41 (in Russ.).

7. S a k o mura N.K., Ek m a y R.D., M e i S.J., C o o n C.N. Lysine, methionine, phenylalanine, arginine, valine, isoleucine, leucine, and threonine maintenance requirements of broiler breeders. Poultry Sci., 2015, 94(11): 2715-2721 (doi: 10.3382/ps/pev287).

8. Chebotarev I.I., Ernst L.K., Samuilenko A.Ya., Fisinin V.I., Panin A.N., Laptev G.Yu., Shkol'nikov E.E. Shtamm Escherichia coli - produtsent lizina, sposob polucheniya kormovoi dobavki, soderzhashchei dannyi shtamm, kompozitsiya, poluchennaya etim sposobom, i sposob kormleniya monogastrichnykh zhivotnykh i ptits. Patent RU 2347807 C1 [Escherichia coli strain, the lysine producer, a method for producing a feed additive containing the strain, a composition obtained by this method, and a method for feeding monogastric animals and birds. Patent RU 2347807 C1]. Appl. December 13, 2007. Publ. February 27, 2009, Bul. № 6 (in Russ.).

9. Livshits V.A., Doroshenko V.G., Mashko S.V., Akhverdyan V.Z., Kozlov Yu.I. Shtamm Escherichia coli - produtsent aminokisloty (varianty) $i$ sposob polucheniya aminokislot (varianty). Patent RU 2212447 C2 [Escherichia coli strain, the amino acid producer (variants), and a method for producing amino acids (variants). Patent RU 2212447 C2]. Appl. April 26, 2000. Publ. September 20, 2003 (in Russ.).

10. Ernst L.K., Laptev G.Yu. Ispol'zovanie rekombinantnykh i nerekombinantnykh mikroorganizmov dlya optimizatsii mikroflory zheludochno-kishechnogo trakta sel'skokhozyaistvennykh zhivotnykh [Recombinant and non-recombinant microorganisms for gut microbiota optimization]. Moscow, 2002 (in Russ.).

11. Ernst L.K., Samuilenko A.Ya. Enterobakterii $v$ zhivotnovodstve [Enterobacteria in animal husbandry]. Moscow, 2011 (in Russ.).

12. Ta raka nov B.V. Metody issledovaniya mikroflory pishchevaritel'nogo trakta sel'skokhozyaistvennykh zhivotnykh i ptitsy [Methods for studying the microflora of the digestive tract in agricultural animals and poultry]. Moscow, 2006 (in Russ.).

13. Chen Y., Sun J., Li a X.P., Shao Y., Li L., Fang L.X., Liu Y.H. Impact of enrofloxacin and florfenicol therapy on the spread of OqxAB gene and intestinal microbiota in chickens. Vet. Microbiol., 2016, 192: 1-9 (doi: 10.1016/j.vetmic.2016.05.014).

14. Fisinin V.I., Chebotarev I.I., Nikonov I.N., Il'ina L.A., Laptev G.Yu., Mashentseva N.G. Biofarmatsevticheskii zhurnal, 2014, 6(6): 60-64 (in Russ.).

15. Laptev G.Yu., Novikova N.I., Il'ina L.A., Iyldyrym E.A., Nagornova K.V., Dumova V.A., Soldatova V.V., Bol'shakov V.N., Gorfunkel' E.P., Dubrovina E.G., Sokolova O.N., Nikonov I.N., Lebedev A.A. Normy soderzhaniya mikroflory $v$ rubtse krupnogo rogatogo skota [Norms of rumen microflora in cattle]. St. Petersburg, 2014 (in Russ.). 
16. Metodika provedeniya nauchnykh i proizvodstvennykh issledovanii po kormleniyu sel'skokhozyaistvennoi ptitsy. Molekulyarno-geneticheskie metody opredeleniya mikroflory kishechnika /Pod redaktsiei V.I. Fisinina [Methods of laboratory and field study on feeding of poultry. Molecular genetic methods for determining intestinal microflora. V.I. Fisinin (ed.)]. Sergiev Posad, 2013 (in Russ.).

17. Bryukhanov A.L., Rybak K.V., Netrusov A.I. Molekulyarnaya mikrobiologiya [Molecular microbiology]. Moscow, 2012 (in Russ.).

18. Maniatis T., Fritsch E.F., Sambrook J. Molecular cloning: A laboratory manual. Cold Spring Harbor, NY, 1982.

19. Mc Cartney A.L. Application of molecular biological methods for studying probiotics and the gut flora. Br. J. Nutr., 2002, 88: 29-37.

20. Kitts C.L. Terminal restriction fragment patterns: a tool for comparing microbial communities and assessing community dynamics. Current Issues in Intestinal Microbiology, 2001, 2: 17-25.

21. Il'ina L.A., Yildirim E.A., Nikonov I.N., Filippova V.A., Laptev G.Yu., Novikova N.I., Grozina A.A., Lenkova T.N., Manukyan V.A., Fisinin V.I., Egorov I.A. Taxons of chicken cecum microbiom are abundant, and influenced by the combined feed composition and decreased metabolizable energy. Agricultural Biology, 2015, 50(6): 817-824 (doi: 10.15389/agrobiology.2015.6.817eng) (in Engl.).

22. Kucan M., Gobin I., Markov K., Jurcic Momcilovic D., Frece J. Testing the adhesion and colonization ability of Lactobacillus plantarum strain S1 to the mice intestinal epithelium. International Journal of Sanitary Engineering Research, 2012, 6(1): 25-30.

23. Ouwehand A.C., Salminen S., Isolaury E. Probiotics: an overview of beneficial effects. Antonie Leewenhoek, 2002, 82: 279-289.

24. Takahashi M., Kametaka M., Mitsuoka T. Influence of diets low in protein or lysine on the intestinal flora of chicks with reference to cecal contents. J. Nutr. Sci. Vitaminol., 1982, 28(5): 501-510. 